\title{
Pineal Gland Plays a Role in Gonadal Development after Eyelids Separation in Puppies
}

\author{
La Glándula Pineal Juega un Rol en el Desarrollo Gonadal \\ Luego de la Separación de los Párpados en Cachorros
}

\author{
Khalil Abou-Easa,"*; Mohammed Abu El-Magd"*; Ehab Tousson***; \\ Amin Hassanin $^{* * * *}$; Mustafa Shukry ${ }^{* * * * *}$ \& Mohammed Salama**
}

ABOU-EASA, K.; EL-MAGD, M. A.; TOUSSON, E; HASSANIN, A.; SHUKRY, M. \& SALAMA, M. Pineal gland plays a role in gonadal development after eyelids separation in puppies. Int. J. Morphol., 33(1):7-18, 2015.

SUMMARY: Several functional and morphological studies have been conducted on the pineal gland in many mammalian species; however, no published reports are available on the role of pineal gland on the gonadal development before and after eyelids separation in puppies. Therefore, this study aimed to trace the postnatal histo-morphological changes in the pineal gland and gonads of puppies before (2,10 and 11 days old) and after (25, 35 and 40 days old) eyelids separation in an attempt to investigate the possible role of pineal gland on the gonadal development. In general, the differentiation of pineal cells, interstitial endocrine cells of testes and stromal ovarian cells coincides with the start of eyelids separation in puppies. Histological examination of stained pineal and gonadal slices of puppies after eyelids separation revealed a remarkable differentiation of pinealocytes and testicular interstitial endocrine cells, as well as presence of some evidence of folliculogenesis in ovary. Surprisingly, melatonin receptor (MT1) protein expression levels were significantly increased in the ovaries and testes of puppies after eyelids separation. Moreover, the mRNA and protein expression of AANAT, a ratelimiting enzyme in melatonin biosynthesis, was notably increased in the pineal gland of opened eyes puppies. Our results suggest an increase of melatonin production from the pineal gland of opened eyes puppies and this could play a vital role in the developmental changes observed in the gonads of these puppies.

KEY WORDS: Pineal; Testis; Ovary; Puppy; Eyelids separation.

\section{INTRODUCTION}

The structure and function of pineal gland of many mammalian species, particularly rodents, have been extensively studied (Bhatnagar, 1992; Abou-Easa et al., 2009). However, relatively few reports are available on the histophysiology of pineal gland and its effect on gonad development and reproduction in domestic animals. It has been reported that the postnatal developmental changes of the pineal gland and gonad are closely correlated and that the pineal gland and its major product, melatonin, play a crucial role in mammalian reproduction (Olcese, 1995). Melatonin is produced by the pineal gland and by various other organs such as gonads and involved in the regulation of the hypothalamic-pituitary-gonadal axis in photoperiodic species (El-Raey et al., 2011). Melatonin blocks the secretion of gonadotropins (luteinizing hormone and follicle stimulating hormone) from the anterior pituitary gland. These hormones are important for gonadal development and function (Lahmam et al., 2008).

Melatonin acts via two types of G-protein-coupled receptors [melatonin receptor type 1 (MT1) and MT2] (Li et al., 2013). The amino acid L-tryptophan, as a precursor to melatonin, participates in multi-step enzymatic reactions to form serotonin. Serotonin is then acetylated by a rate-limiting arylalkylamine $\mathrm{N}$-acetyltransferase (AANAT) into $\mathrm{N}$-acetyl serotonin, which is finally converted into melatonin by hydroxyindole-O-methyl transferase (Axelrod \& Weissbach, 1960). AANAT plays a unique transduction role in vertebrate

\footnotetext{
Department of Cytology and Histology, Faculty of Veterinary Medicine, Kafrelsheikh University, Kafrelsheikh, Egypt.

** Department of Anatomy and Embryology, Faculty of Veterinary Medicine, Kafrelsheikh University, Egypt.

**** Department of Zoology, Faculty of Science, Tanta University, Egypt.

**** Department of Cytology and Histology, Faculty of Veterinary Medicine, Sadat University, Egypt.

****** Department of Physiology, Faculty of Veterinary Medicine, Kafrelsheikh University, Egypt.

******* Department of Biochemistry, Faculty of Veterinary Medicine, Mansoura University, Egypt.
} 
physiology as the key interface between melatonin production and regulatory mechanisms. Circulating melatonin is elevated at night in all vertebrates as the AANAT activity increases in the pineal gland in response to signals from the circadian clock (Arendt, 1998). Melatonin is the primary marker of circadian rhythm in vertebrates. The nocturnal increase in circulating melatonin is mirrored by the increased AANAT protein expression (Ganguly et al., 2001). The synthesis and secretion of melatonin are mainly regulated by the activity of AANAT; this control is exerted at both transcriptional and post-translational levels. Moreover, melatonin biosynthesis is initiated via stimulation of b1-adrenergic receptors by noradrenergic input to the pineal gland. This is mainly originated from the superior cervical ganglion that receives signals from the retina via the suprachiasmatic and paraventricular nuclei in the hypothalamus (Simonneaux \& Ribelayga, 2003). Light affects the circadian clock, making melatonin production occur during night. The duration of melatonin production varies according to the time of year due to the seasonal variation of the day's length (Wehr, 2001).

A synchronism between eye vision and the pineal gland was previously established, where the pineal gland is affected by light-dark (Engel et al., 2005; El Allali et al., 2008; Roa \& del Sol, 2014; Guadarrama-Ortiz et al., 2014). Taken together, the link between pineal gland, gonads, and light could suggest a possible cross-talk between the pineal gland, light, and gonadal development in animals. Therefore, the present study was carried out to check this hypothesis.

\section{MATERIAL AND METHOD}

This work was reviewed and approved by the Animal Care and Welfare Committee of Kafrelsheikh University, Egypt.

Animals and tissues collection. The present study was conducted on twelve male and female puppies before (at ages of 2, 10, and 11 days) and after (at ages of 25, 35, and 40 days) eyelids separation. The puppies are usually born blind with the lid margins still adherent to each other and usually separate about 2 weeks post-partum. Pregnant bitches were kept under supervision until whelping. The bitches and their puppies were apparently healthy and living under natural lighting condition (12/12 h dark/light). Specimens were collected from puppies in the afternoon time at the start of autumn. The puppies were harvested by cutting the jugular vein under general anesthesia in accordance with local and national guidelines covering experimental animals. Pieces of pineal glands, testes and ovaries were fixed in Bouin's fluid,
$10 \%$ formalin, or neutral formol saline for histological analysis. In addition, some pieces of pineal glands were quickly frozen by immersion in liquid nitrogen and stored at $-80^{\circ} \mathrm{C}$ until RNA extraction. All samples for gene and protein expression were collected in daylight and at the same time (at noon) to avoid variation of pineal activities between day and night.

Histological staining. Paraffin sections with 3-7 $\mu \mathrm{m}$ thick were serially cut and then stained with Hematoxylin and Eosin (H\&E), Periodic Acid- Schiff technique (PAS), or PASOrange G method (Bancroft \& Stevens, 1990).

Total RNA isolation. Each pineal gland specimen was homogenized and a total RNA was extracted using total RNA purification kit following the manufacturer protocol (Fermentas, \#K0731, Thermo Fisher Scientific, USA). The extracted RNA was dissolved in nuclease-free water and the concentration and purity were determined using Nanodrop (uv-vis spectrophotometer Q5000, Quawell, USA) by absorption at 260 and $280 \mathrm{~nm}$. The quality and integrity of total RNA were assessed by inspection of the ribosomal RNA bands (18S and 28S) in ethidium bromide-stained $1 \%$ agarose gels under ultraviolet (UV) light and electrophoresis of the RNA confirmed that it was intact. The RNA samples were stored at $-80^{\circ} \mathrm{C}$.

Reverse transcription (RT). Total RNA (5 $\mu$ g per sample) was reverse transcribed into cDNA using Revert Aid H minus Reverse Transcriptase (Fermentas, \#EP0451, Thermo Fisher Scientific, USA) and a mix of oligo (dT) $(0.5 \mu \mathrm{g} /$ reaction $)$, $4 \mu \mathrm{L} 5 \mathrm{X}$ Reaction Buffer, $0.5 \mathrm{mg}$ RNase Inhibitor, $2 \mu \mathrm{L}$ dNTP Mix in a $12.5 \mu \mathrm{L}$ total reaction volume at $42^{\circ} \mathrm{C}$ for 60 $\min$. To terminate the reaction, the tubes were heated at $70^{\circ} \mathrm{C}$ for $10 \mathrm{~min}$ and then were stored at $-80^{\circ} \mathrm{C}$. To avoid residual contamination with genomic DNA, which could lead to falsepositive PCR results, RNA was replaced by RNase free water for a negative control during the RT reaction.

Polymerase chain reaction (PCR). One $\mathrm{mL}$ of $\mathrm{RT}$ reaction product (approximately $50 \mathrm{ng}$ ) was amplified by PCR in final volume of $25 \mu \mathrm{L}$ with $0.5 \mu \mathrm{L}(0.20 \mathrm{mM}) \mathrm{dNTP}, 2.5 \mathrm{~mL}$ buffer, $1.5 \mu \mathrm{L}(2.5 \mathrm{mM}) \mathrm{MgCl} 2,1.0 \mu \mathrm{L} 10 \mathrm{mmol} / \mathrm{L}$ forward primer, $1.0 \mu \mathrm{L} 10 \mathrm{mmol} / \mathrm{L}$ reverse primer, $0.5 \mu \mathrm{L}$ Taq DNA polymerase (5 U/ $\mu \mathrm{L}$, Fermentas, \#K1071, Thermo Fisher Scientific, USA), and 17.0 $\mu \mathrm{L}$ nuclease free water. Thermal cycling parameters were as follows: initial denaturation at $94^{\circ} \mathrm{C}$ for $5 \mathrm{~min}, 35$ cycles of amplification $\left(94^{\circ} \mathrm{C}\right.$ for $30 \mathrm{~s}$ for DNA denaturation, $56^{\circ} \mathrm{C}$ (for Aanat) $/ 57^{\circ} \mathrm{C}$ (for b-actin) for $40 \mathrm{~s}$ annealing temperatures, extension at $72^{\circ} \mathrm{C}$ for 1 $\mathrm{min}$ ), and final extension at $72^{\circ} \mathrm{C}$ for $5 \mathrm{~min}$. The samples were held at $4^{\circ} \mathrm{C}$. PCR products were electrophoresed on $1 \%$ agarose gels using 1 X TAE buffer containing $200 \mathrm{ng} / \mu \mathrm{L}$ ethidium bromide. 
Oligonucleotide primers for amplification of Aanat and b-actin were designed using Primer 5.0 software based on the published nucleotide sequence information of Aanat gene (GenBank accession number NM_001077437) and bactin gene of Canis lupus familiaris (GenBank accession number AF484115). The following primers were used; 1) the forward 5' GGCCGCCTTGTGGCCTTCAT3' and the reverse 5'GGCTGGCTCCCCAGGTGGTA3' for amplification of $191 \mathrm{bp}$ fragment of the dog Aanat, and 2) the forward 5' CGACAACGGCTCCGGCATGT3' and the reverse 5' TGGGCCTCATCGCCCACGT 3' for amplification of $147 \mathrm{bp}$ of the dog b-actin. No amplification product could be detected from any of the negative control specimens, which demonstrated that any contaminating DNA did not amplify using the above-mentioned pairs of primers.

The expected DNA fragments were purified by QIAGEN gel extraction kit (QIAGEN), cloned into the pGEMT easy vector according to the manufacturer's instruction and then sent to MacroGen Company (South Korea) to sequence in both directions using ABI 3730XL DNA sequencer (Applied Biosystem, USA). The sequences were analyzed with Geneious 4.8.4 software. The deduced amino acid sequences were compared with the EMBL Genbank database.

Western blot analysis of MT1 receptor and AANAT protein expression levels. Western blot analysis was carried out to determine MT1 and AANAT protein expression levels in the gonads and pineal glands, respectively, of puppies using the ECL Western blotting analysis system (Amersham Life Science Inc., Arlington Heights, IL). Tissues were lysed in a protein extraction buffer containing Tris $(50 \mathrm{mM}, \mathrm{pH}$ 7.4), EDTA (20 mM), NP-40 (0.5\%), NaCl (150 mM), phenylmethylsulfonyl fluoride $(0.3 \mathrm{mM}), \mathrm{NaF}(1 \mathrm{mM})$, $\mathrm{NaVO}_{4}(1 \mathrm{mM})$, dithiothreitol $(1 \mathrm{mM})$, aprotinin $(1 \mathrm{~g} / \mathrm{ml})$, leupeptine $(11 \mathrm{~g} / \mathrm{ml})$, and pepstatin $(1 \mathrm{~g} / \mathrm{ml})$. The cell lysates were centrifuged for $10 \mathrm{~min}$ at $10,000 \mathrm{~g}$ at $4^{\circ} \mathrm{C}$. Protein concentrations of the supernatants were determined using Bio-Rad protein assay kit (Bio-Rad, Hercules, and CA). Proteins $(150 \mu \mathrm{g})$ were separated by $10 \%$ sodium dodecyl sulfate polyacrylamide gel electrophoresis (SDS-PAGE) and transferred to hybond membranes. After incubation with 5\% nonfat milk in a Tris-buffered saline containing $0.1 \%$ Tween20 , the immunoblots were probed with either anti-MT1 antibody solution (1:500 in blocking buffer as a negative control) or melatonin receptor MT1 antibodies (1:200 in 1\% PBS) (Mel1aR, R-18, Mel1bR, T-18, Santa Cruz Biotechnology, Santa Cruz, CA, USA). For AANAT protein receptors, the membrane was pre-incubated with either control peptide antigen (1:500 in blocking buffer) or polyclonal anti-AANAT (1:1000 in 1\% PBS) (AANAT P-20: sc-55612. Santa Cruz Biotechnology, Santa Cruz, CA, USA). After three washes, membranes were incubated for $1 \mathrm{~h}$ at room temperature with horseradish peroxidase (HRP)-conjugated goat anti-rabbit secondary antibody (1:2000 in 1\% PBS) (Cell Signaling Technology, Beverly, MA, USA). The membranes were then processed using the chemiluminescence system (ECL Amersham Biosciences) and then exposed to X-ray film (Kodak). The same blots were stripped and re-probed with an antibody to $\beta$-actin (1:1000 in 1\% PBS, Calbiochem, La Jolla, CA, USA) as internal loading control. Films were scanned with a densitometer, and protein expression levels were normalized to that of $\beta$-actin.

Statistical data analysis. The band intensities from each blot and gene were quantified using ImageJ software (National Institutes of Health, Bethesda, MD, USA). The data were statistically analyzed by using Graph pad prism ${ }^{\circledR}$ Version 5.0 software (San Diego, CA, USA). The statistical significance of each parameter among groups was evaluated by Student's t-test or the Mann-Whitney U-test (for nonparametric values). P-values of $<0.05$ were considered statistically significant.

\section{RESULTS}

Histological changes in the pineal gland and gonad of puppies before eyelids separation. Analysis of the histological sections of pineal glands of puppies before eyelids separation revealed presence of abundant immature cells of small, dark and tightly packed nuclei in the pineal parenchyma (Fig. 1A, arrowheads). These cells were intermitted by pale-stained areas (Fig. 1A, arrows) containing small blood vessels (Fig. 1A, asterisks). These pineal blood vessels were surrounded by a thick, un-nucleated pale eosinophilic layer. Few pyknotic nuclei of degenerated cells were also seen either isolated or forming groups of two to three cells (Fig. 1B, red arrowhead).

The solid germinal (sex) cords of the testes were loosely arranged and consisted of large primordial germ cells with spherical large nuclei and paler cytoplasm, in addition to small primitive sustentocytes with ovoid nuclei that are either arranged peripherally at the basement membrane or forming a single layer around the primordial germ cells (Fig. 1C). The interstitial endocrine cells could not be demonstrated within the dense interstitial tissue (Fig. 1C, green arrowhead). Unlike in testes, the oogonia were highly proliferative as indicated by presence of a great number of different mitotic stages (Fig.1D). These oogonia were arranged in aggregations and had darkly stained nuclei with irregular contour and pale cytoplasm. 

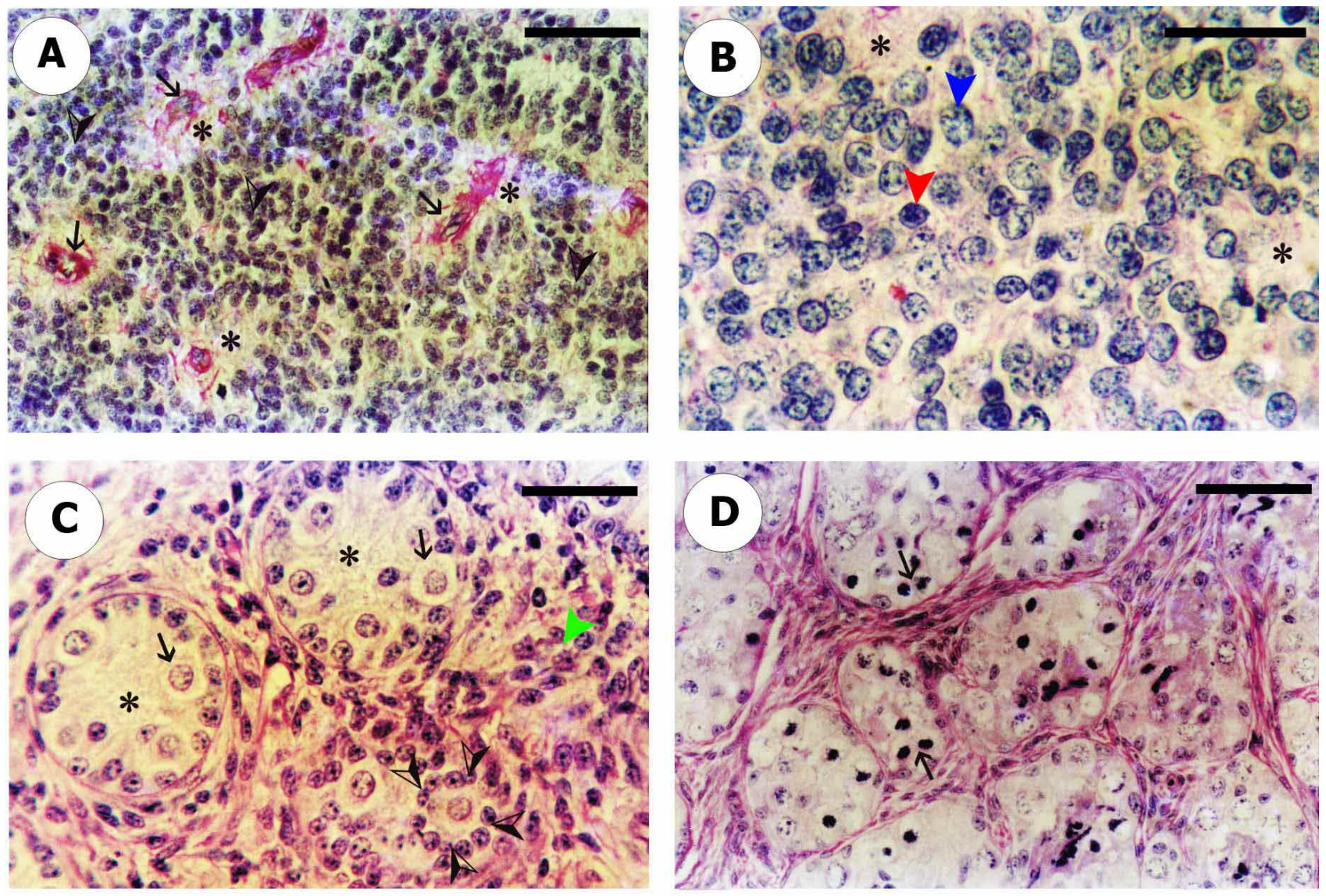

Fig. 1. Histological changes in the pineal gland and gonad of the puppies before eyelids separation. A) Pineal gland of 2-day-old puppy: Dense masses of immature parenchymal cells (arrow heads), pale-stained areas (asterisks) and blood vessels (arrows) (PAS-Orange G). B) Pineal gland of 10-day-old puppy: Immature cells of small, dark and tightly packed nuclei (blue arrowhead), pyknotic nuclei of degenerated cells (red arrowhead), pale-stained areas (asterisks) (PAS). C) Testis of 10-day-old puppy: Sex cords (asterisks), primordial germ cells (arrows), primitive sustecytes (white and black arrowheads) and dense interstitial tissue (green arrowhead) (PAS). D) Ovary of 11-day-old puppy: Aggregated oogonia with more mitotic figures (arrows) (PAS). Scale bars; A, C, D = 30 $\mu \mathrm{m}, \mathrm{B}=15 \mu \mathrm{m}$.

Histological changes in the pineal gland and gonad of puppies after eyelids separation. The nuclear types, characteristic in the adult phase, could be recognized from the 25 days onwards. Most of the cells (which are likely to be pinealocytes) possessed a round/oval nucleus with peripheral clumps of heterochromatin and one or two prominent nucleoli (Figs. 2A and C, blue arrowheads). A second cell type (which is likely to be astrocyte) was characterized by rounded or ovoid darkly stained smaller nucleus with homogeneous chromatin and indistinct nucleoli (Figs. 2A and C, red arrowheads). Another scarce cell type was hardly recognized which is characterized by large pale nucleus and obvious nucleolus (Figs. 2A and C, green arrowheads). These three different cell types were still mixed with smaller, denser nuclei, similar to those described in previous stages in puppies before eyelids separation (Figs. $2 \mathrm{~A}$ and $\mathrm{C}$, yellow arrowheads). The nuclei become widely separated, probably secondary to the hypertrophy of individual cells, and consequently few follicle arrangement of the mature pinealocytes become evident (Fig. 2B). Welldeveloped cell processes were also observed between the parenchymal cells (Fig. 2C, black and white arrowheads).

No remarkable histological changes in the primordial germ cells and the primitive sustentocytes were noticed. However, the interstitial endocrine cells became more differentiated within the interstitial tissues (Fig. 2D). The number of mitotic stages of the oogonia reduced at the age of 25 days (Fig. 2E) and disappeared at the age of 35 days where the primary oocytes differentiated (Fig. 2F). Loosely arranged and moderate numbers of primary oocytes were surrounded by a single layer of flattened cells. The number of the ovarian stromal cells was notably increased (Fig. 2F).

Aanat gene expression in pineal gland. Semi-quantitative RT-PCR method was used to detect the expression of Aanat, that reflects the changes in transcription levels of this gene in pineal gland of puppies before and after eyelids separation, 

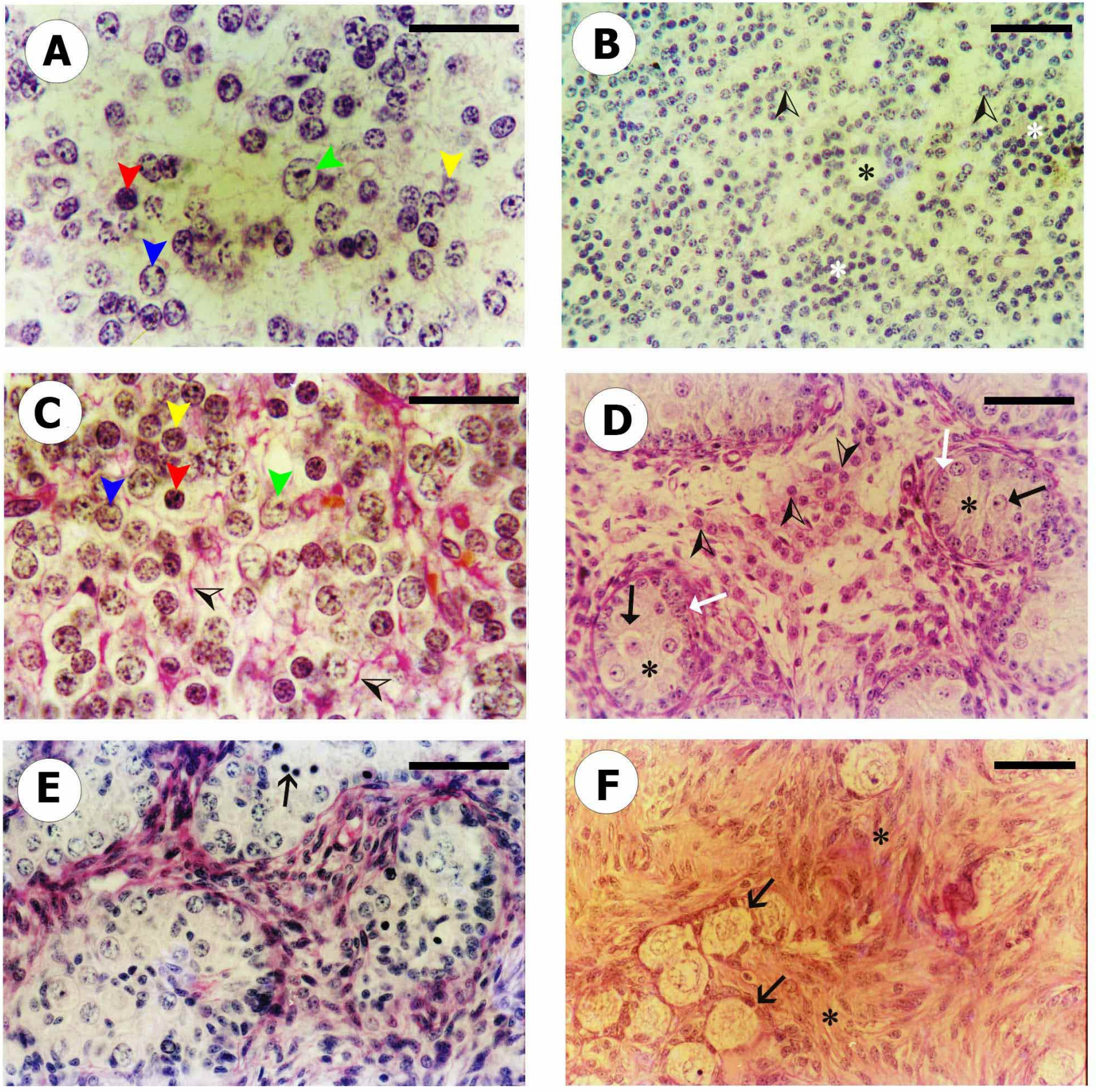

Fig. 2. Histological changes in the pineal gland and gonad of puppies after eyelids separation. A) Pineal gland of 25-day-old puppy: Pinealocytes (blue arrowhead), astrocytes (red arrowhead), cells with large pale nucleus (green arrowhead), immature cells of small, dark and tightly packed nuclei (yellow arrowhead) (H \& E). B) Pineal gland of 35-day-old puppy: Pinealocytes nuclei are loosely distributed (arrowheads), follicle arrangement of cells (black asterisk), and dense areas of immature cells (white asterisks) (H\&E). C) Pineal gland of 40-day-old puppy: Mature pinealocytes (blue arrowhead), astrocytes (red arrowhead), cell processes (black and white arrowheads), cells with large pale nucleus and clear nucleolus (green arrowhead), and immature cells of small, dark and tightly packed nuclei (yellow arrowhead) (PAS-Orange G). D) Testis of 40- day-old puppy: Sex cords (asterisks), primordial germ cells (black arrows), primitive sustentocytes, (white arrows), and interstitial endocrine cells (arrow heads) (PAS). E) Ovary of 25-day-old puppy: oogonia with few mitotic figures (arrow) (PAS). F) Ovary of 35 days old puppy: loose arranged primary oocytes surrounded by a single layer of flattened cells (arrows) and a highly cellular ovarian stroma (asterisks) (PAS). Scale bars; A, C = $15 \mu \mathrm{m}, \mathrm{B}=40 \mu \mathrm{m}, \mathrm{D}-\mathrm{F}=30 \mu \mathrm{m}$.

in comparison to the housekeeping gene, b-actin. Sequence analysis of the amplified PCR products of Aanat confirmed the right amplifications of the desired fragments. Amplicons sequences revealed $100 \%$ identity to the published Aanat 
gene sequences of Canis lupus familiaris (GenBank accession number, NM_001077437) (data not shown).
Expression of Aanat gene was remarkably up-regulated in puppies after eyelids separation (Fig. 3).
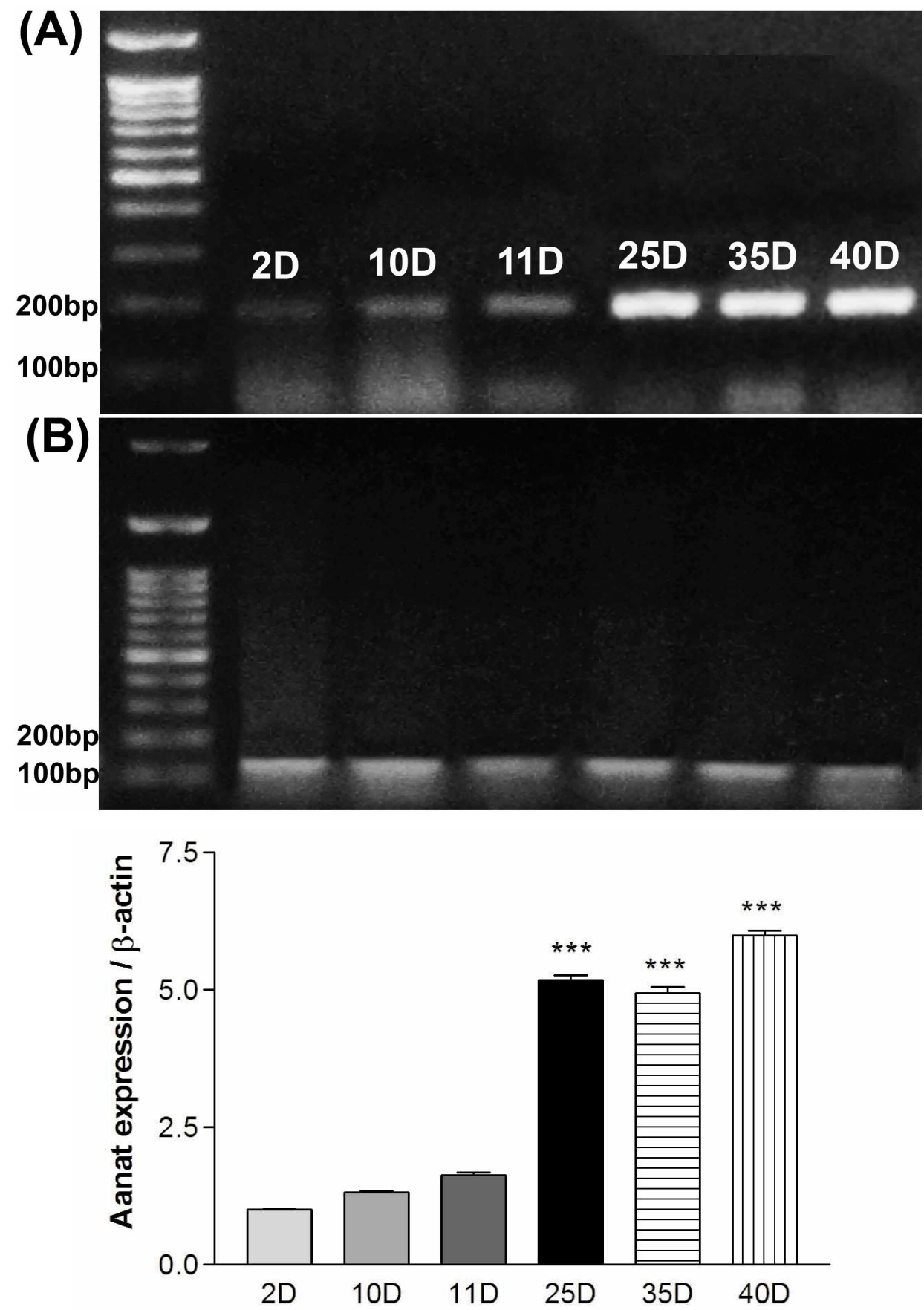

Fig. 3. Aanat gene expression levels in the pineal gland of puppies before (day 2, 10, and 11) and after (day 25, 35, and 40) eyelids separation. A and B) Ethidium bromide stained agarose gel of RT-PCR products Aanat gene with size of $191 \mathrm{bp}$ (A) compared to the house keeping gene, for b actin, with size of $147 \mathrm{bp}(\mathrm{B})$. C) Band intensity was quantified using ImageJ software and the ratio of Aanat to $\mathrm{b}$ actin was calculated. Mean ratios of six samples of three experiments performed on different samples and data are expressed as the mean \pm S.E.M. are represented on this figure, relative to the mean ratio of the 2-day-old puppies. Aanat gene expression levels were significantly higher in puppies after eyelids separation. *** denotes significant difference from 2 day old puppies $(\mathrm{P}<0.05)$. 
MT1R and AANAT protein expression. The expression levels of MT1R protein in testes and ovaries collected from puppies before $(2,10$ and 11 days old) and after $(25,35$ and 40 days old) eyelids separation were detected by Western blot technique. The results showed that MT1R protein expression levels were significantly higher in ovaries (Fig.
4) and testes (Fig. 5) of puppies after eyelids separation, reaching its maximal expression levels at day 40 postpartum. In addition, the expression of AANAT was also extremely higher in the pineal gland tissue of puppies after eyelids separation (Fig. 6).
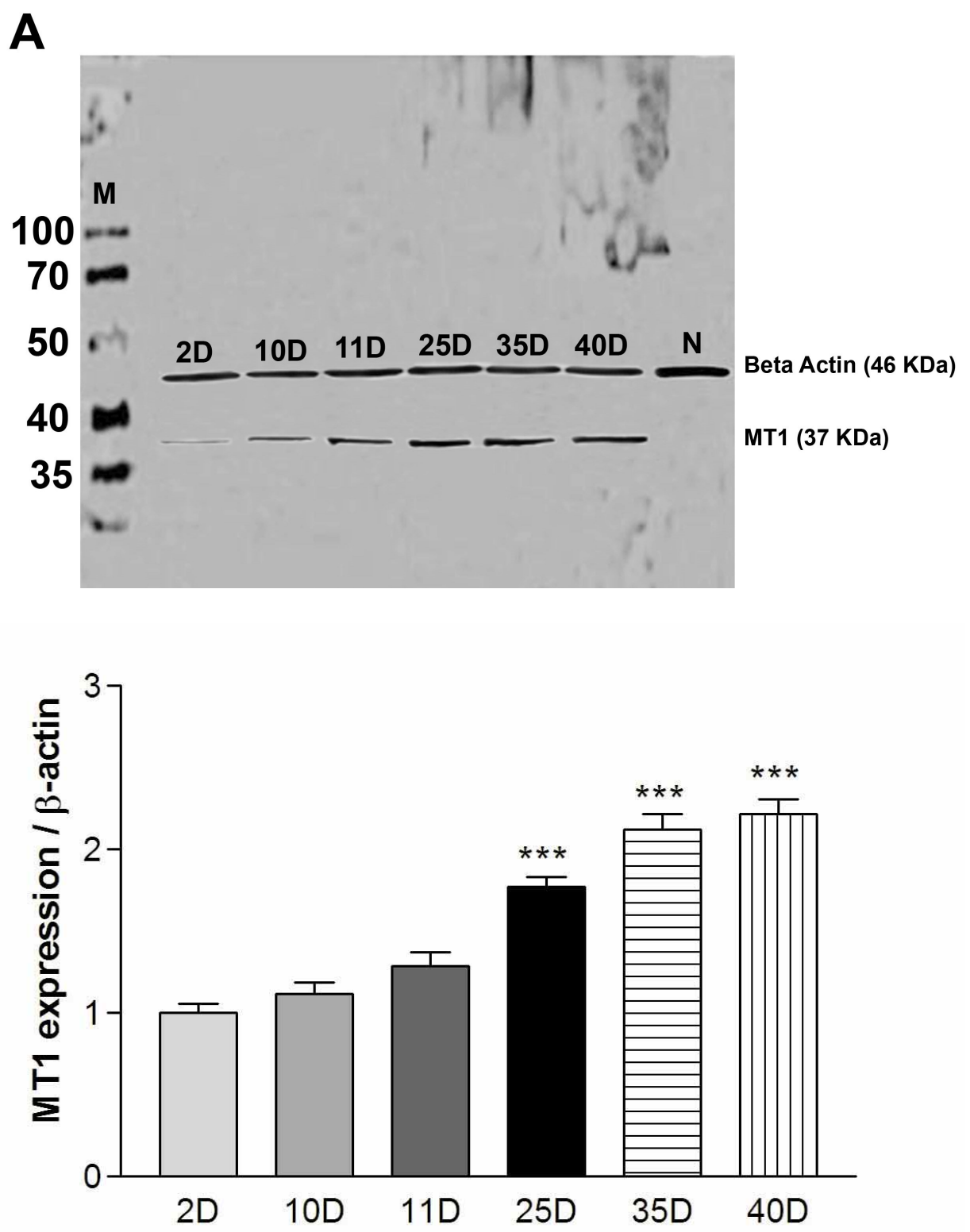

Fig. 4. MT1 protein expression levels in the ovaries of puppies before (day 2, 10, and 11) and after (day 25, 35, and 40) eyelids separation. A) Western blot analysis of ovarian lysates from puppies before and after eyelids separation using an antibody to MT1, b-actin was used as loading control. B) Band intensity was quantified using ImageJ software and the ratio of MT1 to b-actin was calculated. Mean ratios of six samples of three experiments performed on different samples and data are expressed as the mean \pm S.E.M. are represented on this figure, relative to the mean ratio of the 2 day old puppies. MT1 protein was significantly higher in puppies after eyelids separation. *** denotes significant difference from 2-day-old puppies $(\mathrm{P}<0.05)$. $\mathrm{N}=$ Negative control. 

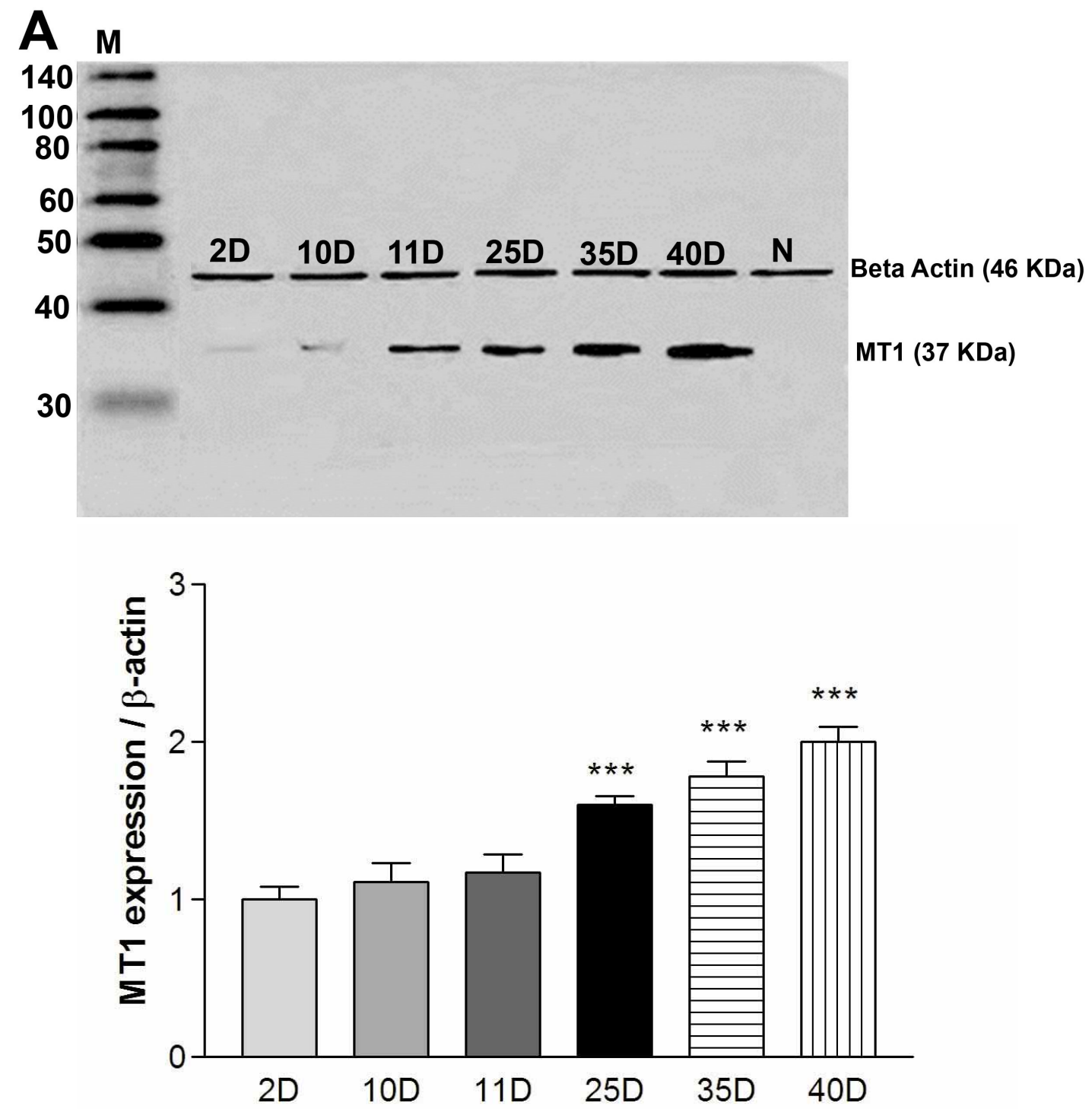

Fig. 5. MT1 protein expression levels in the testes of puppies before (day 2, 10, and 11) and after (day 25, 35, and 40) eyelids separation. A) Western blot analysis of testicular lysates from puppies before and after eyelids separation using an antibody to MT1, b-actin was used as loading control. B) Band intensity was quantified using ImageJ software and the ratio of MT1 to b-actin was calculated. Mean ratios of six samples of three experiments performed on different samples and data are expressed as the mean \pm S.E.M. are represented on this figure, relative to the mean ratio of the 2-day-old puppies. MT1 protein was significantly higher in puppies after eyelids separation. *** denotes significant difference from 2-day-old puppies $(\mathrm{P}<0.05) . \mathrm{N}=$ Negative control.

\section{DISCUSSION}

The current experiment was carried out to study the postnatal changes in the pineal gland and gonads of puppies before and after eyelids separation, and to explore the potential role of pineal gland in the gonadal development in newborn puppies.
In puppies before eyelids separation, the spherical and crowded nuclei of the parenchymal cells of the pineal gland of newborn puppies showed slight differences, yet not enough to make feasible the separation into definite cell types. These cells are most likely immature pinealocytes. In 

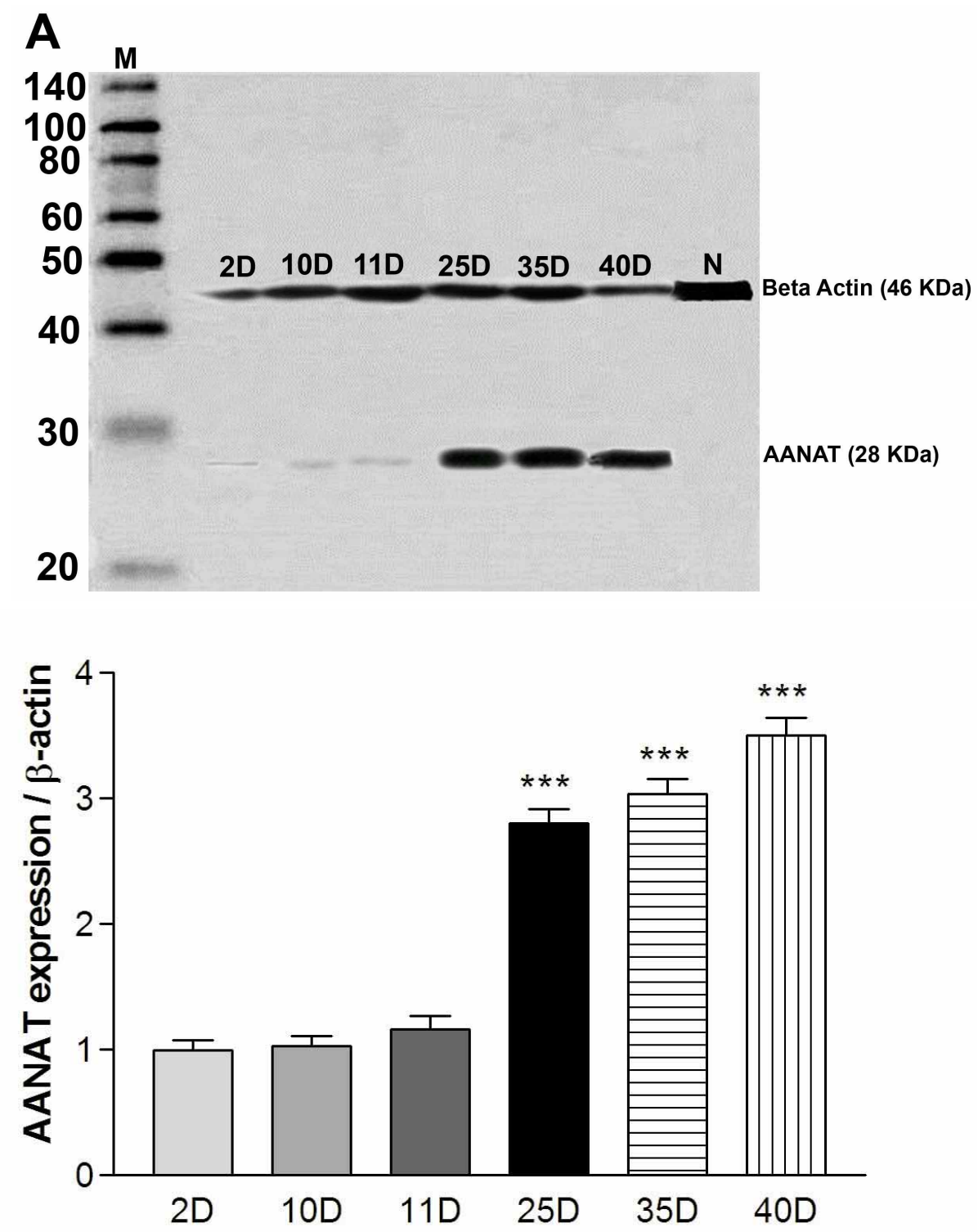

Fig. 6. AANAT protein expression levels in the pineal of puppies before (day 2, 10, and 11) and after (day 25, 35, and 40) eyelids separation. A) Western blot analysis of pineal lysates from puppies before and after eyelids separation using an antibody to AANAT, b-actin was used as loading control. B) Band intensity was quantified using ImageJ software and the ratio of MT1 to b-actin was calculated. Mean ratios of six samples of three experiments performed on different samples and data are expressed as the mean \pm S.E.M. are represented on this figure, relative to the mean ratio of the 2-day-old puppies. AANAT protein levels were significantly higher in puppies after eyelids separation. $* * *$ denotes significant difference from 2-day-old puppies $(\mathrm{p}<0.05) . \mathrm{N}=$ Negative control.

accordance, it has previously been shown that before eyelids separation, the puppies pinealocytes in the first 14 days of the postnatal life and those of rabbit in the first $24 \mathrm{~h}$ of postnatal life were immature cells (Calvo et al., 1988, 1990). On the other hand, after eyelids separation at the age of 25 days in puppies, the pineal cells become differentiated into mature pinealocytes and astrocytes. Similar findings were previously reported. The pineal size was generally larger in puppies after eyelids separation with more developed cell processes. In support to our results, a gradual increase in the pineal gland size was noticed in neonatal puppies (Calvo et al., 1988, 1990). 
In the current study, we have shown that the interstitial endocrine cells of testis became more differentiated in puppies after eyelids separation. However, there was no difference in either primordial germ cells or primitive sustentocytes before or after eyelids separation. Histological analysis has revealed presence of some evidence of folliculogenesis in puppies after eyelids separation in form of remarkable increase of ovarian stromal cells which are necessary for initiation of follicular growth. Nevertheless, the proliferation of the oogonia reduced after separation of eyelids and remarkably decreased at the age of 35 days when the primary oocytes were differentiated. It has been reported that the oogonia were differentiated into primary oocytes during the prenatal life (Hirshfield \& DeSanti, 1995). However, in carnivores, which born with sticky eyelids (blind), the differentiation of oogonia delays till eyelids separation.

Our results showed that the mRNA and protein expression of the rate-limiting enzyme in melatonin biosynthesis, AANAT, was significantly increased in the pineal gland of puppies after separation of eyelids. In agreement with our result, Aanat mRNA was expressed as early as the 4th day of the postnatal life in rats, and gradually increased until puberty (Wongchitrat et al., 2012). Furthermore, Ganguly et al. showed that the expression of AANAT protein was mirrored by an increase in circulating melatonin. Taken together, these findings suggest that melatonin synthesis and secretion by the pineal gland increases in puppies after eyelids separation, and light could play a major role in melatonin biosynthesis. Interestingly, we have also found that the expression level of melatonin receptor (MT1) was significantly higher in the testes and ovaries of puppies after eyelids separation. In agreement, Izzo et al. (2010) have detected a remarkable increase of MT1 mRNA expression in the testis of newborn rats after 2 week of age (after separation of eyelids) as compared to very low expression during the first week of age (before separation of eyelids). Taken together, the developmental changes we observed in testes and ovaries of puppies after eyelids separation are suggested to be under the control of pineal gland's melatonin. Similarly, Vaughan et al. (1994) have observed a close correlation between the postnatal developmental changes of the pineal gland and gonad. In addition, a gradual increase of melatonin serum level was observed in rats from the early postnatal life till the puberty and this increase was necessary for normal reproduction (Reviewed by Olcese, 1995). In contrast, a very old study by Tait et al. (1969) showed that the synthesis of melatonin by the pineal gland was greatest on the first 8 days of postnatal life, but decreased sharply by day-16. The high rate of melatonin synthesis recorded on the first postnatal 8 days was attributed to the darkened state in utero and the unopened and nonfunctional eyes of the neonatal rats. The sharp decrease in melatonin synthesis at day-16 was attributed to the intervening opening of the eyes and the perception of light. Melatonin synthesis by the pineal gland in this study was inversely related to the rapid increase in testicular development after 16 days of age.

Such controversial results on the effect of melatonin and the pineal gland on the gonad was extensively reported (Kang et al., 2009; Shi et al., 2009; Tamura et al., 2009; ElRaey et al.; Rocha et al., 2013). Melatonin was originally believed to be inhibitory to reproduction, i.e. to be antigonadotropic, in photoperiodic animals since prolonged elevation of nocturnal levels of serum melatonin presumably suppressed the hypothalamic-pituitary-gonadal axis resulting in the involution of the reproductive organs in these animals (Reiter, 1973). However, some seasonal breeders, e.g. some breeds of sheep, successfully mate during the winter months when nights are long and melatonin levels are maximal (Bittman et al., 1983). In addition, melatonin implantation into male animals significantly elevated serum testosterone levels which subsequently increased sperm number, motility and the fertilization rate (Casao et al., 2010). Furthermore, eggs fertilized by melatonin-treated sperms have significantly higher developmental rates to the blastocyst stage (Jang et al., 2010). Considering these findings, it is now thought that melatonin is not always antigonadotropic.

In addition to sperm cells, several recent studies indicate that under both in vitro and in vivo conditions, melatonin significantly promotes the maturation and development of oocytes from the cow (Papis et al., 2007) and mouse (Tamura et al.). Moreover, it has been hypothesized that melatonin could regulate follicular development through its endocrine and paracrine action (Tamura et al.). This hypothesis is supported by the presence of melatonin receptors (MT1 and MT2) in bovine and porcine ovarian follicular cells (Kang et al.; ElRaey et al.) and the detection of high melatonin concentrations in porcine follicular fluid (Shi et al.). Recently, it has been demonstrated that melatonin combined with FSH plays an important role in early folliculogenesis in goats, promoting follicular growth in vitro (Rocha et al.).

This is the first study to establish a link between the light, pineal, and gonadal development in dogs. From the results shown in this study, we could conclude that the pineal gland melatonin could play a role in the gonadal development in puppies after eyelids separation, and that the production of pineal gland's melatonin is regulated by light. It is therefore important to do surgical operation to the delayed adherent eyelids of puppies as quickly as possible to avoid delayed maturation of their gonads.

ACKNOWLEDGEMENTS. All experiments were conducted in the Histology Lab and Biotechnology Lab, Faculty of Veterinary Medicine, Kafrelsheikh University, Egypt. 
ABOU-EASA, K.; EL-MAGD, M. A.; TOUSSON, E; HASSANIN, A.; SHUKRY, M. \& SALAMA, M. La glándula pineal juega un rol en el desarrollo gonadal luego de la separación de los párpados en cachorros. Int. J. Morphol., 33(1):7-18, 2014.

RESUMEN: Diversos estudios morfológicos y funcionales han sido realizados sobre la glándula pineal en distintas especies de mamíferos. Sin embargo, no hay informes publicados acerca del rol de la glándula pineal en el desarrollo gonadal antes y después de la separación de los párpados en cachorros. Este estudio tuvo como objetivo trazar los cambios histo-morfológicos postnatales en la glándula pineal y las gónadas de los cachorros antes (2, 10 y 11 días de edad) y después (25, 35 y 40 días de edad) de la separación de los párpados, en un intento por investigar el posible rol de la glándula pineal en el desarrollo gonadal. En general, la diferenciación de los pinealocitos, células intersticiales endocrinas de los testículos y las células estromales del ovario coincide con el inicio de la separación de los párpados en cachorros. El examen histológico de glándula pineal y los cortes gonadales de los cachorros, después de la separación de los párpados, reveló una notable diferenciación de los pinealocitos y las células intersticiales endocrinas testiculares, así como la posible evidencia de foliculogénesis en el ovario. Sorprendentemente, en el receptor de melatonina (MT1) los niveles de expresión de proteínas fueron significativamente superiores en los ovarios y los testículos de los cachorros después de la separación de los párpados. Además, el ARNm y la expresión de la proteína AANAT, una enzima limitante de la velocidad en la biosíntesis de la melatonina, aumentaron notablemente en la glándula pineal de los cachorros con los ojos abiertos. Nuestros resultados sugieren que existe un aumento de la producción de melatonina por parte de la glándula pineal en los cachorros con los ojos abiertos, lo que podría jugar un rol vital en los cambios evolutivos observados enlas gónadas de estos cachorros.

PALABRAS CLAVE: Glándula pineal; Testículos; Ovarios; Cachorros; Separación de párpados.

\section{REFERENCES}

Abou-Easa, K.; Tousson, E. \& Abd-El-Gawad, M. Involution signs during the postnatal life in the pineal tissue of buffalo and camel. Nat. Sci., 7(9):35-44, 2009.

Arendt, J. Melatonin and the pineal gland: influence on mammalian seasonal and circadian physiology. Rev. Reprod., 3(1):13-22, 1998.

Axelrod, J. \& Weissbach, H. Enzymatic O-methylation of Nacetylserotonin to melatonin. Science, 131(3409): 1312, 1960.

Bancroft, J. D. \& Stevens, A. Theory and Practice of Histological Technique. 3rd ed. Edinburgh, Churchill Livingstone, 1990.

Bhatnagar, K. P. The ultrastructure of mammalian pinealocytes: a systematic investigation. Microsc. Res. Tech., 21(2):85-115, 1992.

Bittman, E. L.; Dempsey, R. J. \& Karsch, F. J. Pineal melatonin secretion drives the reproductive response to daylength in the ewe. Endocrinology, 113(6):2276-83, 1983.

Calvo, J.; Boya, J.; García-Mauriño, A. \& López Carbonell, A. Postnatal development of the dog pineal gland. Light microscopy. Histol. Histopathol., 5(1):31-6, 1990.

Calvo, J.; Boya, J. \& Garcia-Mauriño, E. Ultrastructure of the pineal gland in the adult dog. J. Pineal Res., 5(5):479-87, 1988.

Casao, A.; Vega, S.; Palacín, I.; Pérez-Pe, R.; Laviña, A.; Quintín, F. J.; Sevilla, E.; Abecia, J. A.; Cebrián-Pérez, J. A.; Forcada, F. \& Muiño-Blanco, T. Effects of melatonin implants during non-breeding season on sperm motility and reproductive parameters in Rasa Aragonesa rams. Reprod. Domest. Anim., 45(3):425-32, 2010.

El-Raey, M.; Geshi, M.; Somfai, T.; Kaneda, M.; Hirako, M.; AbdelGhaffar, A. E.; Sosa, G. A.; El-Roos, M. E. \& Nagai, T. Evidence of melatonin synthesis in the cumulus oocyte complexes and its role in enhancing oocyte maturation in vitro in cattle. Mol. Reprod. Dev., 78(4):250-62, 2011.

El Allali, K.; Sinitskaya, N.; Bothorel, B.; Achaaban, R.; Pévet, P. \& Simonneaux, V. Daily Aa-nat gene expression in the camel (Camelus dromedarius) pineal gland. Chronobiol. Int., 25(5):800-7, 2008.

Engel, L.; Lorenzkowski, V.; Langer, C.; Rohleder, N. \& Spessert, $\mathrm{R}$. The photoperiod entrains the molecular clock of the rat pineal. Eur. J. Neurosci., 21(8):2297-304, 2005.

Ganguly, S.; Gastel, J. A.; Weller, J. L.; Schwartz, C.; Jaffe, H.; Namboodiri, M. A.; Coon, S. L.; Hickman, A. B.; Rollag, M.; Obsil, T.; Beauverger, P.; Ferry, G.; Boutin, J. A. \& Klein, D. C. Role of a pineal cAMP-operated arylalkylamine Nacetyltransferase/14-3-3-binding switch in melatonin synthesis. Proc. Natl. Acad. Sci. U. S. A., 98(14):8083-8, 2001.

Guadarrama-Ortiz, P.; Ramírez-Aguilar, R.; Madrid-Sánchez, A.; Castillo-Rangel, C.; Carrasco-Alcántara, D. \& AguilarRoblero, R. Aging process entrainment: suprachiasmatic nucleus and pineal gland. Int. J. Morphol., 32(2):409-14, 2014.

Hirshfield, A. N. \& DeSanti, A. M. Patterns of ovarian cell proliferation in rats during the embryonic period and the first three weeks postpartum. Biol. Reprod., 53(5):1208-21, 1995. 
Izzo, G.; Francesco, A.; Ferrara, D.; Campitiello, M. R.; Serino, I.; Minucci, S. \& d'Istria, M. Expression of melatonin (MT1, MT2) and melatonin-related receptors in the adult rat testes and during development. Zygote, 18(3):257-64, 2010.

Jang, H. Y.; Kim, Y. H.; Kim, B. W.; Park, I. C.; Cheong, H. T.; Kim, J. T.; Park, C. K.; Kong, H. S.; Lee, H. K. \& Yang, B. K. Ameliorative effects of melatonin against hydrogen peroxideinduced oxidative stress on boar sperm characteristics and subsequent in vitro embryo development. Reprod. Domest. Anim., 45(6):943-50, 2010.

Kang, J. T.; Koo, O. J.; Kwon, D. K.; Park, H. J.; Jang, G.; Kang, S. K. \& Lee, B. C. Effects of melatonin on in vitro maturation of porcine oocyte and expression of melatonin receptor RNA in cumulus and granulosa cells. J. Pineal Res., 46(1):22-8, 2009.

Lahmam, M.; El M'rabet, A.; Ouarour, A.; Pévet, P.; Challet, E. \& Vuillez, P. Daily behavioral rhythmicity and organization of the suprachiasmatic nuclei in the diurnal rodent, Lemniscomys barbarus. Chronobiol. Int., 25(6):882-904, 2008.

Li, D. Y.; Smith, D. G.; Hardeland, R.; Yang, M. Y.; Xu, H. L.; Zhang, L.; Yin, H. D. \& Zhu, Q. Melatonin receptor genes in vertebrates. Int. J. Mol. Sci., 14(6):11208-23, 2013.

Olcese, J. The mammalian pineal gland and reproduction. Controversies and strategies for future research. Adv. Exp. Med. Biol., 377:1-14, 1995.

Papis, K.; Poleszczuk, O.; Wenta-Muchalska, E. \& Modlinski, J. A. Melatonin effect on bovine embryo development in vitro in relation to oxygen concentration. J. Pineal Res., 43(4):321-6, 2007.

Reiter, R. J. Pineal control of a seasonal reproductive rhythm in male golden hamsters exposed to natural daylight and temperature. Endocrinology, 92(2):423-30, 1973.

Roa, I. \& del Sol, M. Pineal gland morphology - A literature review. Int. J. Morphol., 32(2):515-21, 2014.

Rocha, R. M.; Lima, L. F.; Alves, A. M.; Celestino, J. J.; Matos, M. H.; Lima-Verde, I. B.; Bernuci, M. P.; Lopes, C. A.; Báo, S. N.; Campello, C. C.; Rodrigues, A. P. \& Figueiredo, J. R. IInteraction between melatonin and follicle-stimulating hormone promotes in vitro development of caprine preantral follicles. Domest. Anim. Endocrinol., 44(1):1-9, 2013.

Shi, J. M.; Tian, X. Z.; Zhou, G. B.; Wang, L.; Gao, C.; Zhu, S. E.; Zeng, S. M.; Tian, J. H. \& Liu, G. S. Melatonin exists in porcine follicular fluid and improves in vitro maturation and parthenogenetic development of porcine oocytes. J. Pineal Res., 47(4):318-23, 2009.

Simonneaux, V. \& Ribelayga, C. Generation of the melatonin endocrine message in mammals: a review of the complex regulation of melatonin synthesis by norepinephrine, peptides, and other pineal transmitters. Pharmacol. Rev., 55(2):325-95, 2003.

Tait, G. R.; Barfuss, D. W. \& Ellis, L. C. Pineal gland, melatonin synthesis, and testicular development in the rat. Life Sci., 8(13):717-25, 1969.

Tamura, H.; Nakamura, Y.; Korkmaz, A.; Manchester, L. C.; Tan, D. X.; Sugino, N. \& Reiter, R. J. Melatonin and the ovary: physiological and pathophysiological implications. Fertil. Steril., 92(1):328-43, 2009.

Vaughan, M. K.; Menendez-Pelaez, A.; Buzzell, G. R.; Chambers, J. P. \& Reiter, R. J. Pineal acid phosphatase activity in Syrian hamsters: sex differences and effects of castration and androgen replacement therapy. Endocr. Res., 20(1):89-99, 1994.

Wehr, T. A. Photoperiodism in humans and other primates: evidence and implications. J. Biol. Rhythms, 16(4):348-64, 2001.

Wongchitrat, P.; Govitrapong, P. \& Phansuwan-Pujito, P. The expression of Per1 and Aa-nat genes in the pineal gland of postnatal rats. J. Med. Assoc. Thai., 95(Suppl. 12):S69-75, 2012.

\author{
Correspondence to: \\ Prof. Khalil F. Abou-Easa \\ Head of Department of Cytology and Histology \\ Faculty of Veterinary Medicine \\ Kafrelsheikh University \\ El-Geish Street \\ Kafrelsheikh \\ Post Box 33516 \\ EGYPT
}

Email: khalil_aboueasa@vet.kfs.edu.eg

Received: 14-03-2014

Accepted: 27-06-2014 